\title{
A study of chromium induced allergic contact dermatitis with 54 volunteers: implications for environmental risk assessment
}

\author{
J Nethercott, D Paustenbach, R Adams, J Fowler, J Marks, C Morton, J Taylor, \\ S Horowitz, B Finley
}

\begin{abstract}
Over the past 60 years, dose-response patch test studies by various methods have been conducted in an attempt to identify the minimum elicitation threshold (MET) concentration of hexavalent chromium ( $\mathrm{Cr}(\mathrm{VI})$ ) that produces an allergic response in $\mathrm{Cr}$ (VI) sensitive subjects. These data are not adequate, however, to provide an accurate estimate of the MET because of the variability in the patch testing techniques and the variability in diagnostic criteria used. Furthermore, the data were not reported in terms of mass of allergen per surface area of skin ( $\mathrm{mg} \mathrm{Cr} / \mathrm{cm}^{2}$-skin), which is necessary for conducting occupational or environmental health risk assessments. Thus the purpose of this study was to determine the MET (mg allergen/ $\mathrm{cm}^{2}$ ) for $\mathrm{Cr}$ (VI) and trivalent chromium (Cr(III)) by patch testing techniques. A patch test method that delivers a controlled amount of allergen per surface area of skin was used. A group of $54 \mathrm{Cr}$ (VI) sensitised volunteers were patch tested with serial dilutions of $\mathrm{Cr}$ (VI) and $\mathrm{Cr}$ (III) to determine the cumulative response rate at several concentrations. The results indicate that the $10 \%$ MET for $\mathrm{Cr}(\mathrm{VI})$ based on the cumulative response was $0.089 \mu \mathrm{g}$ $\mathrm{Cr}(\mathrm{VI}) / \mathrm{cm}^{2}$-skin. Only one of the 54 volunteers may have responded to $33 \mu \mathrm{g}$ $\mathrm{Cr}$ (III)/ $\mathrm{cm}^{2}$-skin, otherwise $\mathrm{Cr}$ (III) was unable to produce allergic contact dermatitis in these highly sensitive volunteers. Two supplemental studies were also conducted to assess whether the surface area of the patch and the concentration of $\mathrm{Cr}(\mathrm{VI})$ in the patch (related to patch thickness) were likely to influence the results. The data from these studies were used to assess the risk of developing allergic contact dermatitis due to contact with $\mathrm{Cr}$ (VI) and $\mathrm{Cr}$ (III) in soil. The findings indicated that soil concentrations at least as high as $450 \mathrm{ppm} \mathrm{Cr}$ (VI) and 165000 ppm $\mathrm{Cr}$ (III) should not pose an allergic contact dermatitis hazard for at least $99.99 \%$ of the people in the community who might be exposed.
\end{abstract}

(Occup Environ Med 1994;51:371-380)

Hexavalent chromium $\mathrm{Cr}(\mathrm{VI})$ is one of the most common dermal sensitisers in the occupational setting and accounts for about
$5 \%$ of clinically reported cases of allergic contact dermatitis in the United States. ${ }^{1} \mathrm{Cr}$ (VI) related allergic contact dermatitis has been reported in chromium plating workers, ${ }^{23}$ lithographers, ${ }^{4}$ diesel repair shop workers, ${ }^{5}$ and leather workers. $^{6}$ Additionally, $\mathrm{Cr}$ (VI) in household products such as bleaches and detergents, cosmetics, and shoe polish has been cited as a potential cause of allergic contact dermatitis. ${ }^{17}$ In many areas, there can be appreciable human exposure to chromite ore processing residue (COPR) and mine tailings when either is mixed with soil. ${ }^{8}$

$\mathrm{Cr}(\mathrm{VI})$ induced allergic contact dermatitis is known as a type IV, delayed, or cell mediated allergic reaction. ${ }^{129}$ The localised biological response of allergic contact dermatitis is similar to a "poison oak" hypersensitive reaction, and elicits the standard symptoms of erythema, oedema, and small vesicles. ${ }^{1910}$ Type IV allergic dermatitis reactions are most often not life threatening and their effect is generally limited to the skin. Sensitisation is a threshold response where single or repeated exposure to low doses of an allergen may not produce an allergic response if the threshold dose is not reached. ${ }^{8}$ Epidermal contact with high concentrations of $\mathrm{Cr}(\mathrm{VI})$ can also produce irritant contact dermatitis, which is a heterogeneous symptom wherein a chemical induces a non-immunological dermatitis. ${ }^{11-13}$ A cutaneous irritant causes direct damage to the skin without prior sensitisation. ${ }^{112}$

It has been known since 1925 that dermal contact with $\mathrm{Cr}(\mathrm{VI})$ can elicit allergic dermatoses. ${ }^{14}$ Due to the strong sensitising potential of $\mathrm{Cr}(\mathrm{VI})$ and the desire to reduce the incidence of allergies in workers, several studies involving patch testing have been conducted to determine the "minimum elicitation threshold" (MET) of $\mathrm{Cr}(\mathrm{VI})$ in sensitised persons. ${ }^{15-21}$ In those studies, people known to be $\mathrm{Cr}(\mathrm{VI})$ sensitive were tested with patches containing serial dilutions of $\mathrm{Cr}(\mathrm{VI})$ (usually as potassium dichromate $\left(\mathrm{K}_{2} \mathrm{Cr}_{2} \mathrm{O}_{7}\right)$ ) in petroleum jelly, water, and/or acid-glycine.

Dose-response studies of dermal sensitisers conducted before 1988 were much less complex than those used today. For example, much of the existing patch test data for $\mathrm{Cr}(\mathrm{VI})$ were collected before the improved and standardised diagnostic criteria developed by the North American Contact Dermatitis Group (NACDG) ${ }^{22}$ and the International Contact Dermatitis Research Group (ICDRG). ${ }^{23}$ One deficiency in prior studies is believed to be that some irritant reactions were scored as an allergic response. Early 
reports of $\mathrm{Cr}(\mathrm{VI})$ patch test data often failed to disclose information regarding the diagnostic criteria to determine allergy, duration of application, and the analytical methods used to validate the chromium concentration and valency state. Also, it is known that the patch preparation methods were inconsistent and that interpatch variability of the amount of $\mathrm{Cr}(\mathrm{VI})$ applied could be as high as an order of magnitude. ${ }^{24}$ In some of these previous studies, ${ }^{15-21}$ a patch test was simply a gauze pad that was immersed into the aqueous $\mathrm{Cr}(\mathrm{VI})$ solution before application, an open area of skin covered with tape, or a measured amount of $\mathrm{Cr}(\mathrm{VI})$-petroleum mixture loaded into Finn chambers. At least two recent papers have attempted to identify a MET for $\mathrm{Cr}(\mathrm{VI})$ induced allergic contact dermatitis from these studies. Based on a statistical analysis of patch test data, it has been suggested that $10 \mathrm{ppm}$ $\mathrm{Cr}$ (VI) was the MET at the $10 \%$ response level. ${ }^{25} 26$ Paustenbach et $a l^{27}$ examined the data from the same studies and suggested that the $10 \%$ MET should be about $50 \mathrm{ppm}$ $\mathrm{Cr}(\mathrm{VI})$ in solution.

Certainly, the most important deficiency in these studies with respect to their usefulness in environmental risk assessment is that the data were not reported in terms of mass of allergen per unit area (for example, $\mathrm{mg} / \mathrm{cm}^{2}$ ). As has been discussed elsewhere, by contrast with using patch tests to identify those chemicals to which a person is sensitised (a qualitative decision), in order to perform health risk assessments patch testing data must be presented in terms of $\mathrm{mg}$ of chemical per skin area. ${ }^{24}$ 28-31 $^{2}$ For example, when determining acceptable surface concentrations for toxicants on walls, process equipment, or in soils, uptake per unit area of skin (for example, $\mathrm{mg} / \mathrm{cm}^{2}$-skin) is needed. ${ }^{32}$ This is important because at least one regulatory agency has suggested that allergic contact dermatitis is a proper health endpoint for regulating levels of $\mathrm{Cr}(\mathrm{VI})$ in soils. ${ }^{25}$ Because the existing data do not seem to provide an accurate estimate of the $\mathrm{Cr}(\mathrm{VI}) \mathrm{MET}$ and the data are not adequate to quantitatively predict the health risks related to $\mathrm{Cr}(\mathrm{VI})$ in contaminated media, we conducted a carefully controlled study that used dose per unit area as dosimetric index.

This paper describes the results of a patch test study designed to determine the area based MET $\left(\mu \mathrm{g} \mathrm{Cr} / \mathrm{cm}^{2}\right.$ skin) of solubilised $\mathrm{Cr}$ (VI) and $\mathrm{Cr}$ (III) that will elicit allergic contact dermatitis in chromium sensitised subjects. Under the direction of several members of the NACDG, a group of 54 volunteers known to be sensitised to $\mathrm{Cr}(\mathrm{VI})$ were patch tested with serial dilutions of $\mathrm{Cr}(\mathrm{VI})$ and $\mathrm{Cr}$ (III). To reduce the variability inherent in

Table 1 Chromium (Cr(VI) and Cr(III)) concentrations used in the patch testing study

\begin{tabular}{llll}
\hline $\begin{array}{l}\text { Potassium dichromate } \\
\left(\mu \mathrm{g} \mathrm{K}_{2} \mathrm{Cr}_{2} \mathrm{O} / \mathrm{cm}{ }^{2}\right)\end{array}$ & $\begin{array}{l}\text { Concentration per unit } \\
\text { area }\left(\mu \mathrm{Cr}(\mathrm{VI}) / \mathrm{cm}^{2}\right)\end{array}$ & $\begin{array}{l}\text { Chromium trichloride } \\
\left(\mu \mathrm{g} \mathrm{CrCl} \mathrm{Cl}_{3} / \mathrm{cm}^{2}\right)\end{array}$ & $\begin{array}{l}\text { Concentration per unit } \\
\text { area }\left(\mu \mathrm{G} \mathrm{Cr}(\mathrm{III}) / \mathrm{cm}^{2}\right)\end{array}$ \\
\hline 12.5 (diagnostic) & 4.4 & 100 & 33.0 \\
2.5 & 0.88 & 20 & 6.6 \\
0.5 & 0.18 & 10 & 3.3 \\
0.25 & 0.088 & 2 & 0.66 \\
0.05 & 0.018 & & \\
\hline
\end{tabular}

earlier patch preparation methods, "TRUETest" patches were specifically manufactured for use in this study.

\section{Materials and methods}

In general, as the water solubility of a $\mathrm{Cr}$ (VI) salt increases, its ability to penetrate the skin barrier and elicit allergic contact dermatitis increases. ${ }^{33}$ Due to its high degree of water solubility, $\mathrm{K}_{2} \mathrm{Cr}_{2} \mathrm{O}_{7}$ is one of the most penetrating and therefore most potentially reactive $\mathrm{Cr}(\mathrm{VI})$ species $^{834}$ Potassium dichromate is currently used by members of the NACDG and ICDRG as the standard Cr(VI) patch test agent for diagnostic purposes..$^{23} 3536$ Accordingly, for the purposes of this study, $\mathrm{K}_{2} \mathrm{Cr}_{2} \mathrm{O}_{7}$ was chosen as the test $\mathrm{Cr}(\mathrm{VI})$ compound. Trivalent $\mathrm{Cr}$ compounds are not routinely used for clinical patch testing because $\mathrm{Cr}$ (III) is considered to have little or no allergic potential. ${ }^{37-39}$ This is due, in part, to the low water solubility of most $\mathrm{Cr}$ (III) compounds and the long history of uneventful occupational exposure. ${ }^{3340}$ Chromium trichloride $\left(\mathrm{CrCl}_{3}\right)$ was used in this study because it is one of the most water soluble $\mathrm{Cr}$ (III) species. ${ }^{34}$ Chromium trichloride has also been used in some earlier patch testing studies. ${ }^{41} 42$

TRUE-Test (thin layer rapid use epicutaneous test) gel matrix patches were manufactured by Kabi Pharmacia Research Center AS, Inc, Hillerod, Denmark. Table 1 presents the patch concentrations of $\mathrm{K}_{2} \mathrm{Cr}_{2} \mathrm{O}_{7}$ and $\mathrm{CrCl}_{3}$ used in this study. Patches containing $\mathrm{K}_{2} \mathrm{Cr}_{2} \mathrm{O}_{7}$ were prepared by mixing $\mathrm{K}_{2} \mathrm{Cr}_{2} \mathrm{O}_{7}$ (purity 98.5-101.5\%) with a wet hydroxypropyl cellulose gel to the specified concentrations. The patches containing $\mathrm{CrCl}_{3}$ were prepared by mixing $\mathrm{CrCl}_{3}$ with a wet polyvidone gel to the appropriate concentrations. These gels have little or no sensitising potential. ${ }^{24} 3643$ The allergens were mixed to a specified mass of $\mathrm{Cr}(\mathrm{VI})$ or $\mathrm{Cr}$ (III) per unit area, printed on a sheet of polyester, and dried to a thin film. These coated water impermeable sheets were then cut into square patches of $0.81 \mathrm{~cm}^{2}$, mounted on a piece of adhesive, non-allergenic tape, and packaged in an airtight and light impermeable envelope. The $\mathrm{K}_{2} \mathrm{Cr}_{2} \mathrm{O}_{7}$ test patches were also sealed with desiccant paper to prevent adsorption of moisture.

The TRUE-Test patches are specifically designed to hydrate by perspiration when taped to the skin under occlusion. The dried film is hydrated into a gel thickness of 50 to $70 \mu \mathrm{m}$ from which the allergen migrates to the skin. The hydrated gel, occluded by adhesive backing and plastic, ensures maximal contact with the skin, thus enabling high allergen bioavailability. ${ }^{35}$ With this approach, the allergen is evenly distributed over the test area and the quantitative dose of allergen challenge is accurately controlled. ${ }^{24} 3044$ This provides a significant advantage over other current techniques, such as the Finn chamber, in which the mass of allergen loaded on to the skin may vary by up to an order of magnitude from patch to patch. ${ }^{24}$ 
ANALYTICAL VALIDATION OF PATCH CONCENTRATIONS

Analytical confirmation of the patch concentrations was conducted before performing the study to ensure that each patch contained the appropriate valency and concentration of $\mathrm{Cr}$. The concentrations of $\mathrm{Cr}(\mathrm{VI})$ in the patch were determined with Modified NIOSH Method $7600^{45}$ as the extraction procedure and inductively coupled-visible absorption spectrometry (IC-VAS) ${ }^{46}$ to measure the solubilised $\mathrm{Cr}(\mathrm{VI})$. Modified NIOSH Method 7600 is essentially a modified version of EPA Method 3060, ${ }^{47}$ with slight differences in preparation and buffer solutions. A single patch was immersed in $25 \mathrm{ml}$ of extraction solution $(1.7 \mathrm{~g}$ of $0.2 \mathrm{M}$ sodium bicarbonate in 1.0 litre distilled water). The polyethylene bottle was capped and ultrasonicated for about three hours, at which time the bottles were removed and placed in a rotating shaker for 48 hours at room temperature. The extractant was then injected into an ion chromatograph where the $\mathrm{Cr}(\mathrm{VI})$ was eluted with an ammonium sulphate and ammonium hydroxide eluent mixture. After elution from the column, the $\mathrm{Cr}(\mathrm{VI})$ was reacted with 1,5diphenylcarbohydrazide (DPC) and the peak area absorbance of the coloured DPC-Cr(VI) complex was photometrically measured at $520 \mathrm{~nm}$. The $\mathrm{CrCl}_{3}$ patches were also analysed by the modified NIOSH Method 7600/IC-VAS to ensure that $\mathrm{Cr}$ (VI) was not present in the $\mathrm{Cr}$ (III) patches.

The concentrations of $\mathrm{Cr}$ (III) in the patches were determined by EPA Method $3050^{48}$ for extraction and EPA Method $6010^{49}$ for analysis. A modified EPA Method 3050 was used to extract the $\mathrm{Cr}$ (III) patches. Specifically, single patches were added to 1.5 $\mathrm{ml}$ of $0.1 \mathrm{M}$ sodium hydroxide and heated to $85^{\circ} \mathrm{C}$ for one hour, followed by the addition of $300 \mu \mathrm{l} 30 \%$ hydrogen peroxide and heat for another hour. Two millilitres of $0.1 \mathrm{M}$ hydrochloric acid were added to the digestant after heating and the solution was cooled to room temperature. Another $2.2 \mathrm{ml} 0 \cdot 1 \mathrm{M}$ hydrochloric acid was then added to the solution and the volume was adjusted to $25 \mathrm{ml}$ with purified water. The patch digestants were then analysed for total $\mathrm{Cr}$ (as $\mathrm{CrCl}_{3}$ ) by EPA Method 6010, or Inductively Coupled Plasma (ICP). The EPA Method 6010 measures element emitted light by optical spectrometry at $267.7 \mathrm{~nm}$. After the $\mathrm{CrCl}_{3}$ is digested, the ICP column is calibrated with stock solutions of $2 \mathrm{ml}(1: 1) \mathrm{HNO}_{3}$ and $10 \mathrm{ml}$ (1:1) HCL and diluted to $100 \mathrm{ml}$ with type II water. The digestant is directly injected into the column (about $2 \mathrm{ml}$ ) through the torch and a direct reading is taken from the instrument.

Representative patches of each $\mathrm{Cr}$ concentration were analysed in duplicate to evaluate interpatch variability. As part of the confirmation analyses, matrix spikes and matrix spike duplicates (MS/MSDs) were analysed by spiking selected patches with $10 \mu \mathrm{l}$ of $\mathrm{K}_{2} \mathrm{Cr}_{2} \mathrm{O}_{7}$ at a concentration 10 times that of the patch concentration to assess recovery. The
$\mathrm{K}_{2} \mathrm{Cr}_{2} \mathrm{O}_{7}$ patches analysed by modified NIOSH 7600/IC-VAS were within 89-101\% of the theoretical $\mathrm{Cr}(\mathrm{VI})$ concentrations. Also, the MS/MSDs averaged $121 \%$ and $111.5 \%$ for the $4.4 \mu \mathrm{g} \mathrm{Cr}(\mathrm{VI}) / \mathrm{cm}^{2}$ and $0.018 \mu \mathrm{g}$ $\mathrm{Cr}(\mathrm{VI}) / \mathrm{cm}^{2}$ patches with reported relative percentage differences (RPDs) of $2 \%$ for both. Therefore, the patch concentrations were within Contract Laboratory Procedure (CLP) criteria for acceptable variability ( $\pm 25 \%$ ). Additionally, the $\mathrm{K}_{2} \mathrm{Cr}_{2} \mathrm{O}_{7}$ patches analysed for total $\mathrm{Cr}$ using EPA Method 6010 were within $88-97 \%$ of the theoretical total $\mathrm{Cr}$ concentrations. The MS/MSDs measured for the $4.4 \mu \mathrm{g} \mathrm{Cr}(\mathrm{VI}) / \mathrm{cm}^{2}$ patch were both $106 \%$. We analysed the data by SYSTAT version 5.0 by the paired $t$ test with a $95 \%$ confidence level and the data sets were not statistically different. Hence, the $\mathrm{Cr}(\mathrm{VI})$ concentrations measured were considered to be stable in the hexavalent form and in the appropriate amounts.

The concentrations of total $\mathrm{Cr}$ in the $\mathrm{Cr}$ (III) patches ranged from $89 \%-105 \%$ of the theoretical concentrations. The MS/MSDs measured for the $33 \mu \mathrm{g}$ $\mathrm{Cr}(\mathrm{III}) / \mathrm{cm}^{2}$ concentration were $90 \%$ and $80 \%$ respectively. The $0.33 \mu \mathrm{g} \mathrm{Cr}(\mathrm{III}) / \mathrm{cm}^{2}$ MS/MSD concentrations were $110 \%$ and $113 \%$, respectively, with reported $\mathrm{RPDs}$ of $3 \%$ for both. The $\mathrm{Cr}$ (III) patches were also analysed for $\mathrm{Cr}(\mathrm{VI})$ by the modified NIOSH 7600/IC-VAS method and none was found. In summary, these analyses were reproducible and within the CLP acceptable range. Blank patches were also analysed for $\mathrm{Cr}(\mathrm{VI})$ and $\mathrm{Cr}$ (III). No $\mathrm{Cr}$ was detected on either patches using reported limits of $0.00025 \mathrm{mg} / \mathrm{cm}^{2}$ for $\mathrm{Cr}$ (III) and $0.000015 \mathrm{mg} / \mathrm{cm}^{2}$ for $\mathrm{Cr}(\mathrm{VI})$. Representative patches were reanalysed about every three months, and, in every instance, the appropriate valency states and concentrations did not change (less than 5\%) throughout the duration of the study (about one year).

\section{STUDY DESIGN}

\section{Patch concentrations}

The $\operatorname{Cr}(\mathrm{VI})$ patch concentrations used in this study were chosen based on our best estimates of a range that would provide a maximal $(100 \%)$ response at the highest concentration and a minimal response $(<10 \%)$ at the lowest concentration. This is similar to the design of other patch testing studies. ${ }^{28}$ Based on the theoretical underpinnings of the doseresponse relation ${ }^{50}$ our review of the literature suggested that an approximate 250 -fold range of $\mathrm{Cr}(\mathrm{VI})$ concentrations from 0.018 to $4 \cdot 4 \mu \mathrm{g} \mathrm{Cr}(\mathrm{VI}) / \mathrm{cm}^{2}$ would yield useful results. Similarly, for $\operatorname{Cr}$ (III), a 50-fold range of concentrations $\left(0.66-33 \mu \mathrm{g} \mathrm{Cr}(\mathrm{III}) / \mathrm{cm}^{2}\right)$ was chosen based on previously published data. ${ }^{51}$

\section{Patch testing strategy}

The patch testing study was designed to occur in three rounds. In the first round, all subjects were tested with a diagnostic $\mathrm{Cr}(\mathrm{VI})$ patch $\left(4 \cdot 4 \mu \mathrm{g} \mathrm{Cr}(\mathrm{VI}) / \mathrm{cm}^{2}\right)$ to confirm that all volunteers in the study were allergic to $\mathrm{Cr}(\mathrm{VI})$. 
Those who were confirmed as sensitised in round one were then tested in round two with the two lowest $\mathrm{Cr}(\mathrm{VI})$ concentrations and all four $\mathrm{Cr}$ (III) concentrations. If the subjects responded to both of the $\mathrm{Cr}(\mathrm{VI})$ patches or only to the higher concentration $(0.088 \mu \mathrm{g}$ $\mathrm{Cr}(\mathrm{VI}) / \mathrm{cm}^{2}$ ), a threshold was considered to have been identified and the subjects did not complete round three. If no response occurred at either of the two low $\mathrm{Cr}(\mathrm{VI})$ concentrations, then the subjects were tested in round three with the two higher $\mathrm{Cr}(\mathrm{VI})$ concentrations. For each subject, the lowest $\mathrm{Cr}(\mathrm{VI})$ concentration at which a positive response occurred was considered to be the MET for that subject.

The rationale for testing with low $\mathrm{Cr}(\mathrm{VI})$ concentrations initially, followed by higher concentrations if necessary, was to minimise the incidence of "false positives" and "excited skin syndrome" that can occur when multiple patches are applied to the subject's skin in a single dosing. ${ }^{52-54}$ Indeed, many of the earlier reported positive responses to low $\mathrm{Cr}(\mathrm{VI})$ concentrations almost certainly were falsepositives resulting from multiple testing. ${ }^{82-55}$ Patch testing with $\mathrm{Cr}$ (III) was performed in one round of testing (round two) as the $\mathrm{Cr}$ (III) patches were not expected to elicit a response in most of the subjects. All test patches were supplied to the physicians under code to double blind the study. The purpose of blinding was to achieve unbiased readings of the test results by the study physicians. Only one physician evaluated each patient. The physicians received approval from their respective human use committees as appropriate.

\section{Population size}

Before starting the study, an analysis was performed to estimate the total number of subjects required to achieve acceptable statistical power. Our goal was to identify a lower threshold at which no more than $10 \%$ of the $\mathrm{Cr}(\mathrm{VI})$ sensitive subjects would respond with $90 \%$ confidence. A figure of $10 \%$ was used since a number of dermatologists indicated that it would be very difficult to accurately identify through testing a $1 \%-5 \%$ value because $10 \%$ is probably very close to the threshold dose for all people (including the most sensitised). Estimating the number of subjects needed for the study required an assumption about the number of responders at a particular test concentration. Based on results of previous reports ${ }^{56}$ we concluded that about $50-80$ subjects would be required to meet these criteria.

It was anticipated that a number of the subjects may have actually had irritant, atopic, or "excited skin syndrome" reactions,

Table 2 Description of $\mathrm{Cr}(V I)$ sensitised volunteers who participated in the study

\begin{tabular}{lllll}
\hline Sex & $\begin{array}{l}\text { No } \\
\text { originally patch } \\
\text { Tested }\end{array}$ & $\begin{array}{l}\text { No who } \\
\text { qualified and } \\
\text { participated }\end{array}$ & $\begin{array}{l}\text { Range of ages } \\
(y)\end{array}$ & $\begin{array}{l}\text { Average age } \\
(y(S D))\end{array}$ \\
\hline Men & 78 & 39 & $24-74$ & $45 \cdot 6(12 \cdot 6)$ \\
Women & 24 & 15 & $25-59$ & $39 \cdot 6(10 \cdot 3)$ \\
\hline
\end{tabular}

rather than a true allergic contact dermatitis response during previous testing and that about $80 \%$ of the initial subjects would, on round one testing, show a strong positive response to $\mathrm{Cr}(\mathrm{VI})$. Of these, it was estimated that at least $75 \%$ of sensitised persons would consent to participate in the proposed studies and complete the required testing rounds. The drop out rate for these subjects was not known, but was not expected to exceed $10 \%$ $20 \%$. In summary, to have a study population of no less than 50 subjects, it was determined that we needed to find about $100 \mathrm{Cr}(\mathrm{VI})$ sensitised volunteers.

\section{PARTICIPATING PHYSICIANS AND STUDY \\ POPULATION}

Participating physicians

Six practising dermatologists conducted the clinical aspects of the study (Dr Robert Adams, Dr Joseph Fowler, Dr James Marks, Dr Charles Morton, Dr James Nethercott, and Dr James Taylor). They also participated in the study design.

\section{Study population}

More than 6000 patient files from various dermatologists (who specialised in patch testing) were examined before 100 possible volunteers were identified. Eventually, a group of 113 potential subjects were found by the participating physicians, of which 102 eventually took part in the study (11 subjects dropped out due to personal reasons). All were believed to be $\mathrm{Cr}(\mathrm{VI})$ sensitised based primarily on previous clinical patch tests performed by these physicians. As presented in table 2, this initial study population consisted of 78 men $(76 \%)$ and 24 women (24\%). All were over 18 years of age. Persons taking immunosuppressive or steroidal medications and pregnant women were excluded from the study. Subjects with eczema at the scheduled time of testing were not tested until the dermatitis subsided and it was requested that topical steroids not be used for two weeks before testing. All volunteers provided their doctors with written consent to participate in the study.

\section{Patient questionnaire}

Before initial testing, each patient filled out a medical and occupational history questionnaire. Each questionnaire was screened by a qualified person to insure proper completion. The medical history discussed in the form included incidence, type, and duration of past present dermatitis and other known allergies including asthma and any other skin problems or sensitivities. The questionnaire also asked for history of jobs held and corresponding duration, as well as any known or potential exposure to $\mathrm{Cr}$ in the workplace. Use of over the counter medications and vitamins was also recorded. The purpose of collecting this information was to assess whether previous exposure to $\mathrm{Cr}$ compounds was a significant factor in individual METs.

Information on allergic and atopic dermatitis was available for all of the 102 subjects. 
Table 3 Summary of occupations of the 54 Cr(IV) sensitised volunteers who participated in the study

\begin{tabular}{|c|c|}
\hline Occupation & No of people \\
\hline Accounting & 2 \\
\hline Art dealer & 1 \\
\hline Brick mason * & 3 \\
\hline Carpenter & 2 \\
\hline Carpet layer & $\overline{1}$ \\
\hline Cement mason/finisher ${ }^{\star}$ & 4 \\
\hline Truck driver (concrete) & 1 \\
\hline Core driller` & 1 \\
\hline Electrician & 1 \\
\hline Engineer & 2 \\
\hline Gardener & $\mathbf{1}$ \\
\hline Horse trainer & 1 \\
\hline Insulation installer & 1 \\
\hline Lab technician & 2 \\
\hline Mechanic & 1 \\
\hline Medical assistant & 1 \\
\hline Photoengraver* & 3 \\
\hline Plumber (retired) & 1 \\
\hline Print estimator & 1 \\
\hline Production manager & 2 \\
\hline Publisher & 1 \\
\hline Real estate associate & 1 \\
\hline Retired & 5 \\
\hline Saw cutter & 1 \\
\hline Secretary & 5 \\
\hline Self employed & 1 \\
\hline Student & 1 \\
\hline Teacher educator & 3 \\
\hline Tyre changer & 1 \\
\hline Transit operator & 1 \\
\hline Warehouse worker & 1 \\
\hline Unemployed & 1 \\
\hline
\end{tabular}

^Construction related jobs.

Present or past atopic dermatitis was present in $15 \%$ of those who completed the study (eight people). This is in keeping with previous data relating to the prevalence of allergic contact dermatitis. Only $22 \%$ of the volunteers worked in the construction industry or a related field and a significant number of participants had no known previous occupational exposure to $\mathrm{Cr}(\mathrm{VI})$ (table 3 ).

\section{PATCH TESTING PROCEDURE}

In each round of testing, all patches were applied to the upper sides of the back at $7 \mathrm{~cm}$ apart and fixed with Scanpor or paper tape for total occlusion with each patient serving as his or her own control. The patches remained in place for 48 hours, at which time they were removed and readings were taken then and at 96 hours. Test sites with positive reactions after the 96 hour exposure duration were photographed. For each patch in each round, the physicians recorded one of the following responses:

$1=$ Weak (no vesicular) reaction: erythema, infiltration, papules $(+)$

$2=$ Strong (oedematous or vesicular) reaction $(++)$

3 = Extreme (spreading, bullous, ulcerative) reaction $(++)$

$4=$ Doubtful reaction, macular erythema only (?)

5 = Irritant morphology

$6=$ Negative reaction $(-)$

$7=$ Not tested

For the purposes of this study, any degree of positive response (1-3), including a very weak response, was considered to be positive. This is consistent with current NACDG criteria for patch test interpretation. ${ }^{35}$

Round one testing took place between June and September 1992. The first round con- sisted of testing subjects with a TRUE-Test diagnostic patch concentration of $4.4 \mu \mathrm{g}$ $\mathrm{Cr}(\mathrm{VI}) / \mathrm{cm}^{2}$ and a control patch (containing only hydroxypropyl cellulose) to verify sensitisation to $\operatorname{Cr}(\mathrm{VI})$. The patches were removed after 48 hours and an initial reading of the test site was recorded. The final reading, along with photographs of the test sites, was taken 96 hours after patch application. Those who developed an allergic response were considered to be $\mathrm{Cr}(\mathrm{VI})$ sensitised and qualified for round two testing of the study. Three weeks after round one was completed, those with definite positive reactions were tested in round two.

Round two testing took place between July and October 1992. The second test round consisted of patch testing volunteers with 0.018 and $0.088 \mu \mathrm{g} \mathrm{Cr}(\mathrm{VI}) / \mathrm{cm}^{2}$ and all four $\mathrm{Cr}$ (III) concentrations $(0.66,3 \cdot 3,6 \cdot 6$, and 33 $\left.\mu \mathrm{g} \mathrm{Cr}(\mathrm{III}) / \mathrm{cm}^{2}\right)$. Control patches consisting of blank hydroxypropyl cellulose and polyvidone were also tested. The patches were removed after 48 hours and an initial reading of the test site was recorded. The final reading, along with photographs of the test sites, was taken 96 hours after patch application.

Round three testing took place between August and December 1992. Those volunteers showing responses to both 0.018 and $0.088 \mu \mathrm{g} \mathrm{Cr}(\mathrm{VI}) / \mathrm{cm}^{2}$ or to only the $0.088 \mu \mathrm{g}$ $\mathrm{Cr}(\mathrm{VI}) / \mathrm{cm}^{2}$ patch concentrations were not tested in round three. Those who did not respond to either of the two lowest $\mathrm{Cr}(\mathrm{VI})$ concentrations were tested in the third round with the two highest $\mathrm{Cr}(\mathrm{VI})$ concentrations $\left(0.18\right.$ and $\left.0.88 \mu \mathrm{g}-\mathrm{Cr}(\mathrm{VI}) / \mathrm{cm}^{2}\right)$. Any who had anomalous results in round two (positive reaction to $0.018 \mathrm{Cr}(\mathrm{VI}) / \mathrm{cm}^{2}$ but not to $0.088 \mu \mathrm{g}$ $\mathrm{Cr}(\mathrm{VI}) / \mathrm{cm}^{2}$ ) were retested in round three with all four $\mathrm{Cr}(\mathrm{VI})$ concentrations. The round three patches were removed after 48 hours of application and an initial reading of the test site was recorded. The final reading, along with photographs of the test sites, was taken 96 hours after patch application. All volunteers tested in round three were given a three week interval between round two and round three testing.

\section{Patch test results \\ Round one}

Of the 102 people who were initially selected for the study, only 54 responded positively $(+,++$, or +++$)$ to the diagnostic $\mathrm{Cr}(\mathrm{VI})$ patch $\left(4 \cdot 4 \mu \mathrm{g} \mathrm{Cr}(\mathrm{VI}) / \mathrm{cm}^{2}\right)$. This response rate $(47 \%)$ was far less than the projected estimate of $80 \%$, but still yielded enough people (54) to provide statistically significant results. The 54 subjects who proceeded to round two of the study consisted of 39 men $(72 \%)$ and 15 women $(28 \%)$. The men ranged in age from 25-74 (mean 47.9) years; the women from 25-59 (mean $41 \cdot 2$ ) years.

\section{Round two}

In round two, four of 54 subjects (7\%) responded positively to $0.088 \mu \mathrm{g} \mathrm{Cr}(\mathrm{VI}) / \mathrm{cm}^{2}$ but not to $0.018 \mu \mathrm{g} \mathrm{Cr}(\mathrm{VI}) / \mathrm{cm}^{2}$. Accordingly, a 
Table 4 Cumulative dermal response of $54 \mathrm{Cr}$ (VI) sensitised volunteers to various concentrations of $\mathrm{Cr}(\mathrm{VI})$

\begin{tabular}{lcc}
\hline $\operatorname{Cr}(V I)\left(\mu \mathrm{g} / \mathrm{cm}^{2}\right)$ & $\begin{array}{l}\text { Minimum elicitation threshold } \\
\text { response (\%) }\end{array}$ & Cumulative response (\%) \\
\hline 0.018 & $1 / 54(2)$ & $1 / 54(2)$ \\
0.088 & $4 / 54(7)$ & $5 / 54(9)$ \\
0.18 & $5 / 54(9)$ & $10 / 54(19)$ \\
0.88 & $22 / 54(41)$ & $32 / 54(59)$ \\
$4 \cdot 4$ & $22 / 54(41)$ & $54 / 54(100)$ \\
\hline
\end{tabular}

Table 5 Cumulative response of $54 \mathrm{Cr}(V I)$ sensitised volunteers to various concentrations of $\mathrm{Cr}$ (III)

\begin{tabular}{ll}
\hline Cr$(I I I)$ concentration $\left(\mu \mathrm{g} / \mathrm{cm}^{2}\right)$ & Cumulative response (\%) \\
\hline 0.66 & $0 / 54(0)$ \\
3.3 & $0 / 54(0)$ \\
6.6 & $0 / 54(0)$ \\
33 & $1 / 54(0)^{\star}$ \\
\hline
\end{tabular}

`This person, on retest, did not respond to this concentration of Cr(III).

MET of $0.088 \mu \mathrm{g} \mathrm{Cr}(\mathrm{VI}) / \mathrm{cm}^{2}$ was recorded for these four people and they were not required to complete round three. Only one of $54(2 \%)$ responded positively to both 0.018 $\mu \mathrm{g}-\mathrm{Cr}(\mathrm{VI}) / \mathrm{cm}^{2}$ and $0.088 \mu \mathrm{g} \quad \mathrm{Cr}(\mathrm{VI}) / \mathrm{cm}^{2}$. Accordingly, a MET of $0.018 \mu \mathrm{g} \mathrm{Cr}(\mathrm{VI}) / \mathrm{cm}^{2}$ was recorded for this person and he was not required to complete round three. Forty nine of the 54 subjects did not respond to either concentration and, therefore, proceeded to round three. One person had a weak response at the highest $\mathrm{Cr}$ (III) concentration tested (33 $\left.\mu \mathrm{g} \mathrm{Cr}(\mathrm{III}) / \mathrm{cm}^{2}\right)$. On retesting to confirm the weak response, this person failed to elicit a positive response to $33 \mu \mathrm{g} \mathrm{Cr}(\mathrm{III}) / \mathrm{cm}^{2}$. The remaining 53 volunteers also failed to respond positively to any of the $\mathrm{Cr}$ (III) concentrations.

\section{Round three}

In round three, one of the 49 subjects responded to both 0.88 and $0.18 \mu \mathrm{g}$ $\mathrm{Cr}(\mathrm{VI}) / \mathrm{cm}^{2}$. Accordingly, the MET for this person was recorded as $0.18 \mu \mathrm{g} \mathrm{Cr}(\mathrm{VI}) / \mathrm{cm}^{2}$. Also, 22 subjects responded to $0.88 \mu \mathrm{g}$

\footnotetext{
Cumulative response of 54 $\mathrm{Cr}(V I)$ sensitised volunteers to test patches containing various concentrations of $\mathrm{Cr}(V I)$.
}

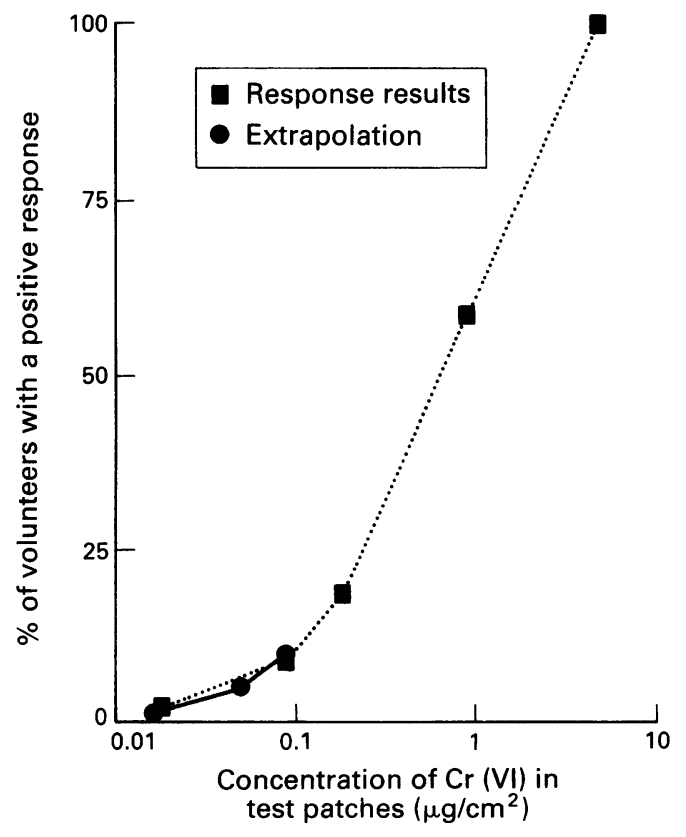

$\mathrm{Cr}(\mathrm{VI}) / \mathrm{cm}^{2}$, but not $0.18 \mu \mathrm{g} \mathrm{Cr}$ (III) $/ \mathrm{cm}^{2}$, and therefore $0.88 \mu \mathrm{g} \mathrm{Cr}(\mathrm{VI}) / \mathrm{cm}^{2}$ was recorded as the MET for those subjects. Twenty two of the volunteers tested in round three had no response to either concentration. Because these volunteers did not respond to any patch concentration less than the diagnostic patch, the MET recorded for them was $4.4 \mu \mathrm{g}$ $\mathrm{Cr}(\mathrm{VI}) / \mathrm{cm}^{2}$. Tables 4 and 5 present the MET and cumulative frequency of response for $\mathrm{Cr}(\mathrm{VI})$ and $\mathrm{Cr}(\mathrm{III})$. The figure presents the dose-response curve.

\section{STATISTICAL ANALYSIS OF RESULTS}

The data were analysed by a computer modelled data technique. ${ }^{58} \mathrm{~A}$ truncated $\log$ normal distribution was fitted to the data with maximum likelihood methods, which is a technique for choosing parameters of a selected distribution of the observed data such that the probability of response of the observed data is maximised. ${ }^{59}$ The fit to the data was excellent as confirmed by the $\chi^{2}$ goodness of fit test, which gave a $p$ value of $>0.05$. The $10 \%$ cumulative response MET for $\mathrm{Cr}(\mathrm{VI})$ was $0.089 \mu \mathrm{g} / \mathrm{cm}^{2}$. The $\log$ normal distribution is conventionally used in the analysis of bioassay data and was used here. ${ }^{60}$ Because a reaction at the maximum tested concentration was a criterion for inclusion in the study, the distribution of response concentrations is truncated. Thus the truncated $\log$ normal distribution was fitted to the dataset with the highest truncation point being the highest $\mathrm{Cr}(\mathrm{VI})$ concentration tested $\left(4 \cdot 4 \mu \mathrm{g} \mathrm{Cr}(\mathrm{VI}) / \mathrm{cm}^{2}\right)$.

\section{IMPORTANCE OF PATCH CONCENTRATION}

Recently, some dermatologists have concluded that the mass of allergen per unit area of skin is the correct measure of dermal dose, not the applied patch concentration of allergen. ${ }^{29}$ To assess the influence of the concentration in the patch test material $v$ the dose applied in mass per unit area on the potential to elicit a response, two different sets of patches were prepared. The first set was prepared with the gel material normally used to manufacture the $0.88 \mu \mathrm{g} \mathrm{Cr}(\mathrm{VI}) / \mathrm{cm}^{2}$ patch. A second patch was constructed from the same gel but it was only $1 / 7$ as thick (the thin patch). Hence, the thin patches contained $0.13 \mu \mathrm{g} \mathrm{Cr}(\mathrm{VI}) / \mathrm{cm}^{2}$, but were identical to the $0.88 \mu \mathrm{g} \mathrm{Cr}(\mathrm{VI}) / \mathrm{cm}^{2}$ patch with respect to mass of $\mathrm{Cr}(\mathrm{VI})$ per mass of patch (in this case, $175 \mathrm{ppm})$

These patches were then evaluated with nine volunteers previously shown to have a MET of $0.88 \mu \mathrm{g} \mathrm{Cr}(\mathrm{VI}) / \mathrm{cm}^{2}$. The results (table 6) indicate that six of the nine subjects showed a response deemed to be morphologically positive at $0.88 \mu \mathrm{g} \mathrm{Cr}(\mathrm{VI}) / \mathrm{cm}^{2}$ but none showed such a response at $0.13 \mu \mathrm{g} \mathrm{r}(\mathrm{VI}) / \mathrm{cm}^{2}$. Thus although both patches were identical on a mass of $\mathrm{Cr}(\mathrm{VI}) / \mathrm{mass}$ of patch basis (175 "ppm" $\mathrm{Cr}(\mathrm{VI})$ ) the elicited response was different indicating that mass per unit arrea is a more appropriate measure of dose. Hence, as predicted by Upadhye and Maibach, ${ }^{29}$ the mass of allergen per unit area of skin, and not the mass of $\mathrm{Cr}(\mathrm{VI}) /$ mass of patch (concentra- 
Table 6 Response of volunteers to patches containing identical PPM concentrations of Cr(VI) (mass of Cr(VI)/mass of patch) but differing mass loading of $\mathrm{Cr}(\mathrm{VI}) / \mathrm{cm}^{2}$

\begin{tabular}{lll}
\hline & \multicolumn{2}{l}{ Patch concentration } \\
\cline { 2 - 3 } Subject & $0 \cdot 13 \mu g \mathrm{Cr}(\mathrm{VI}) / \mathrm{cm}^{2}$ & $0.88 \mu \mathrm{g} \mathrm{Cr}(\mathrm{VI}) / \mathrm{cm}^{2}$ \\
\hline 1 & Negative & Negative \\
2 & Doubtul & Positive \\
3 & Negative & Positive \\
4 & Doubtful & Positive \\
5 & Negative & Positive \\
6 & Negative & Positive \\
7 & Negative & Positive \\
8 & Negative & Negative \\
9 & Negative & Negative \\
\hline
\end{tabular}

tion in ppm) is the critical factor to quantitatively characterise the dermal hazard.

\section{IMPORTANCE OF PATCH SURFACE AREA}

In the past, it has been suggested that if the surface area of the standard patch was significantly increased, then a sub-MET dose per unit area might produce a response because the total systemic uptake of the chemical would be greater. To assess whether patches of a larger surface area might elicit a response at concentrations lower than the METs identified in this study, another study was conducted. Four volunteers who had previously been shown to have a MET of $0.88 \mu \mathrm{g}$ $\mathrm{Cr}(\mathrm{VI}) / \mathrm{cm}^{2}$ were patch tested with five $0 \cdot 18$ $\mu \mathrm{g} \mathrm{Cr}(\mathrm{VI}) / \mathrm{cm}^{2}$ patches placed side by side. Hence, the total amount of allergen required to elicit allergic contact dermatitis in a standard patch was applied, but over a larger surface area. The results showed that sub-MET concentrations of $\mathrm{Cr}(\mathrm{VI})$ applied over a larger skin surface area did not elicit the positive responses seen when the MET concentration was applied in the standard patch. These results support the belief that to produce allergic contact dermatitis, the concentration of allergen delivered to the target organ (the Langerhans cell) in a given area of skin is the correct dosimetric index for evaluating the dermal allergic contact dermatitis hazard.

\section{Discussion}

The results of this study corroborate earlier reports that $\mathrm{Cr}(\mathrm{VI})$ sensitive persons respond to serial dilutions of $\mathrm{Cr}(\mathrm{VI})$ in a fairly linear manner at moderate concentrations. ${ }^{16-18} 2021$ Interestingly, almost half $(22 / 54)$ of the $\mathrm{Cr}(\mathrm{VI})$ sensitised volunteers in this study did not respond to $\mathrm{Cr}(\mathrm{VI})$ concentrations less than the diagnostic concentration of $4.4 \mu \mathrm{g}$ $\mathrm{Cr}(\mathrm{VI}) / \mathrm{cm}^{2}$. The diagnostic patch contains a fairly high $\mathrm{Cr}(\mathrm{VI})$ concentration that is unlikely to be found in the environment and most workplaces. ${ }^{8}$

Many of the subjects who failed to respond in round one had been thought by the physicians to be $\mathrm{Cr}(\mathrm{VI})$ sensitive due to earlier instances of positive responses to $0.5 \%$ $\mathrm{K}_{2} \mathrm{Cr}_{2} \mathrm{O}_{7}$ in petroleum jelly or to $0.25 \%$ $\mathrm{K}_{2} \mathrm{Cr}_{2} \mathrm{O}_{7}$ in TRUE-Test matrix. As discussed earlier, $0.5 \% \mathrm{~K}_{2} \mathrm{Cr}_{2} \mathrm{O}_{7}$ is no longer commonly used clinically in the United States due to the high rate of irritant (non-allergic) responses, ${ }^{143}$ although it is still used in Europe. Many dermatologists in North America believe that use of $0.25 \% \mathrm{~K}_{2} \mathrm{Cr}_{2} \mathrm{O}_{7}$ to identify sensitisation, as was done in this study, minimises or eliminates the incidence of irritant reactions. ${ }^{36}$ Therefore, it is likely that many of those volunteers who initially reacted to $0.5 \% \mathrm{~K}_{2} \mathrm{Cr}_{2} \mathrm{O}_{7}$ exhibited an irritant (false positive) reaction in earlier testing and that the $0.25 \% \quad \mathrm{~K}_{2} \mathrm{Cr}_{2} \mathrm{O}_{7}$ patch used in this study failed to produce the irritant response. Alternatively, it is possible that some of the subjects who failed to respond in round one truly are $\mathrm{Cr}(\mathrm{VI})$ sensitive but have a threshold that is greater than $0.25 \% \mathrm{~K}_{2} \mathrm{Cr}_{2} \mathrm{O}_{7}$. If this is true, then the results of our study could be considered "worst case" as only the hypersensitive volunteers were used to represent the sensitised population.

The results of this study suggest that the $10 \%$ MET for $\mathrm{Cr}(\mathrm{VI})$ induced allergic contact dermatitis is approximately $0.089 \mu \mathrm{g}$ $\mathrm{Cr}(\mathrm{VI}) / \mathrm{cm}^{2}$. No significant correlations between age, sex, or occupation were found at any of the tested concentrations.

Several estimates of the prevalence of $\mathrm{Cr}(\mathrm{VI})$ related allergic contact dermatitis in the general population have been published in the past three years. Hostynek and Maibach estimated that less than $1 \%$ of the general population is $\mathrm{Cr}(\mathrm{VI})$ sensitive based on their review of several years of clinical data. ${ }^{7}$ Paustenbach et al ${ }^{8}$ estimated that about $0.7 \%$ of the general population is $\mathrm{Cr}(\mathrm{VI})$ sensitive. Finally, in a review of clinical data collected from several hundred human volunteers, Nethercott ${ }^{57}$ estimated that "a $0.6 \%$ prevalence is likely a reasonable reflection of the prevalence of $\mathrm{Cr}(\mathrm{VI})$ sensitivity in the general population, although false positive irritant responses to $0.5 \% \mathrm{~K}_{2} \mathrm{Cr}_{2} \mathrm{O}_{7}$ in petroleum jelly may explain even some of these responses." In all three analyses, if one excludes those who have had more than 10 years of experience working with wet cement, the prevalence of $\mathrm{Cr}(\mathrm{VI})$ sensitisation in the general population is probably no greater than $0 \cdot 1 \%$. Therefore, if $\mathrm{Cr}(\mathrm{VI})$ sensitised subjects comprise less than $0.1 \%$ of the general population, an allergic contact dermatitis based soil clean up criterion that is protective of $10 \%$ of the $\mathrm{Cr}(\mathrm{VI})$ sensitised population will probably be protective of about $99.99 \%$ of the general population.

When attempting to use these data to identify safe concentrations of $\mathrm{Cr}(\mathrm{VI})$ in environmental media (soil, dust, etc), it is necessary to consider whether children are more or less prone to $\mathrm{Cr}(\mathrm{VI})$ sensitisation than adults. In general, most authorities believe that sensitivity to contact allergens increases with age, due primarily to increased exposure. ${ }^{6263}$ Children under the age of three react less often and less intensely than older children, whereas children older than three react to contact allergens in a manner similar to adults. ${ }^{6465}$ In studies of patients in paediatric dermatology clinics, Schachner et $a l^{66}$ diagnosed contact dermatitis in only $1.2 \%$ of children tested with $\mathrm{K}_{2} \mathrm{Cr}_{2} \mathrm{O}_{7}$. Romaguera et $a l^{67}$ reported positive reactions in 11 of 1023 children tested $(1 \cdot 1 \%)$ and Tunnessen ${ }^{68}$ reported a similar prevalence rate of $2.4 \%$. In a study of 
Soil concentration (mg-allergen/kg-soil) $=\frac{\operatorname{MET}\left(\frac{\mathrm{mg} \text {-allergen }}{\mathrm{cm}^{2} \text {-skin }}\right) \times \operatorname{CF}\left(\frac{10^{6} \mathrm{mg} \text {-soil }}{\mathrm{kg} \text {-soil }}\right)}{\operatorname{SA}\left(\frac{\mathrm{mg} \text {-soil }}{\mathrm{cm}^{2} \text {-skin }}\right) \times \text { BVA (unitless) }}$

422 paediatric patients, Angelini and Meneghini ${ }^{69}$ concluded that: $(a)$ sensitisation can occur in children as well as adults, but is extremely rare in the first few years of life; (b) the incidence of allergic contact dermatitis increases with age and escalates significantly from the age of 12 years, primarily because of increased exposure to environmental sensitisers and, perhaps, a fully matured immune system; and (c) the patch testing technique employed in adults, with the same substances and concentrations, is also well suited for diagnostic purposes in children. Thus the METs identified in our study can be considered applicable to children as well as adults.

It is noteworthy that there is some uncertainty associated with reading a patch test response as an allergic $v$ an irritant reaction. Nethercott ${ }^{57}$ has stated that the incidence of "misread" test sites can be as high as $20 \%$. Because the patch test reactions in this study were interpreted by members of the NACDG this rate should be much less as the interpretation of patch tests is a routine part of their practice. Because it is more common to misread irritant reactions as allergic than discount an allergic reaction as an irritant one, ${ }^{43}$ the MET estimated from this study can be considered conservative (no less than predicted here).

\section{CALCULATING ACCEPTABLE SOIL} CONCENTRATIONS FOR Cr(VI)

As described by Horowitz and Finley, ${ }^{31}$ an acceptable concentration of allergen in soil can be derived as above: Where MET = the minimum elicitation threshold determined from patch test data; $\mathrm{CF}=$ conversion factor; $\mathrm{SA}=$ soil adherence factor; $\mathrm{BVA}=$ bioavailability.

If the leachability (bioavailability) of the allergen from soil to skin is less than $100 \%$, then the soil concentration must be adjusted upwards accordingly.

The $10 \% \mathrm{MET}$ for $\mathrm{Cr}(\mathrm{VI})$ in sensitised people, as identified in the patch testing study, was $0.089 \mu \mathrm{g} \mathrm{Cr}(\mathrm{VI}) / \mathrm{cm}^{2}$ skin. As discussed previously, a threshold derived from a 48 hour, occluded patch test study is highly conservative (health protective) with respect to realistic environmental exposures. Accordingly, to remain consistent with USEPA's "reasonable maximal exposure" philosophy of risk assessment (wherein average and upper bound values are combined to give a "reasonable" estimate, rather than simply compounding worst case assumptions), it is appropriate to use an average value to represent soil adherence. The USEPA's suggested average value of $0.20 \mathrm{mg} / \mathrm{soil} \mathrm{cm}^{2}$-skin was used for this analysis.

With these values for MET and soil adherence factor, it can be estimated that a concentration of $445 \mathrm{mg} \mathrm{Cr}(\mathrm{VI}) / \mathrm{kg}$ soil (445 ppm) should be acceptable. Hence, even if it were conservatively assumed that all $\mathrm{Cr}(\mathrm{VI})$ in chromite ore processing residue adhering to skin was able to leach into skin moisture and cross the skin barrier, a chromite ore processing residue concentration of $445 \mathrm{ppm} \mathrm{Cr}(\mathrm{VI})$ should protect the vast majority of the $\mathrm{Cr}(\mathrm{VI})$ sensitised population from the allergic contact dermatitis hazard. As noted by Horowitz and Finley ${ }^{70}$ however, extraction of chromite ore processing residue containing up to $1240 \mathrm{mg}$ $\mathrm{Cr}(\mathrm{VI}) / \mathrm{kg}$ soil failed to leach more than $0 \cdot 1 \%$ of the $\mathrm{Cr}(\mathrm{VI})$. Hence, chromite processing residue concentrations much higher than 445 ppm $\mathrm{Cr}(\mathrm{VI})$ should also be health protective for even those people who are very allergic to chromium. As soil cleanup concentrations of about $400 \mathrm{ppm} \mathrm{Cr}(\mathrm{VI})$ or greater are considered to be health protective for the more traditional exposure pathways (soil ingestion and particulate inhalation), it seems that elicitation of allergic contact dermatitis on contact with chromite ore processing residue could occur only at $\mathrm{Cr}(\mathrm{VI})$ concentrations much higher than the soil concentrations that may pose other hazards.

\section{CALCULATING ACCEPTABLE SOIL} CONCENTRATIONS FOR Cr(III)

For the purpose of calculating a $\mathrm{Cr}$ (III) concentration in soil, if one conservatively assumes a $10 \%$ MET at the maximum tested dose used in this study ( $33 \mu \mathrm{g} \mathrm{Cr}$ (III) $/ \mathrm{cm}^{2}-$ skin), the concentration that should not pose an allergic contract dermatitis hazard is $165000 \mathrm{mg} \mathrm{Cr}$ (IIII)/kg-soil (assuming a soil adherence factor of $0.20 \mathrm{mg}$-soil $/ \mathrm{cm}^{2}$-skin and $100 \%$ leachability. Adjustment for less than $100 \%$ leachability would yield a chromite ore processing residue concentration of high hundreds of thousands of ppm. In short, it is implausible that soil contaminated with Cr(III) could pose a dermal hazard.

\section{Conclusions}

This patch testing study was designed to determine a MET for $\mathrm{Cr}(\mathrm{VI})$ induced allergic contact dermatitis on a $\mathrm{mg} \mathrm{Cr}(\mathrm{VI}) / \mathrm{cm}^{2}$ skin basis so that the results could be used to perform occupational and environmental risk assessment. The results suggest that the $10 \%$ MET for $\mathrm{Cr}(\mathrm{VI})$ induced allergic contact dermatitis is about $0.089 \mu \mathrm{g} / \mathrm{cm}^{2}$. It was also shown that the concentration (in ppm) in the patch was not as relevant a dosimetric index as dose per area. With quantitative risk assessment principles, these patch test data were used to identify safe concentrations of $\mathrm{Cr}(\mathrm{VI})$ in soil.

The regulatory concern about $\mathrm{Cr}(\mathrm{VI})$ in 
soil was born of the belief that because $\mathrm{Cr}(\mathrm{VI})$ sensitisation can occur in the workplace, environmental exposure to $\mathrm{Cr}(\mathrm{VI})$ in a soil matrix might also elicit allergic contact dermatitis. Initial estimates of the likely safe concentrations of $\mathrm{Cr}(\mathrm{VI})$ in soil were based on patch testing data from the $1950 \mathrm{~s}$ and $1960 \mathrm{~s}^{51}$; however, as stated previously, there is a high degree of uncertainty associated with those data. Furthermore, the results of those studies were not reported in terms of $\mathrm{mg} \mathrm{Cr}(\mathrm{VI}) / \mathrm{cm}^{2}$ skin.

The results of this patch test study were used to develop soil clean up levels which should prevent the elicitation of allergic contact dermatitis even in sensitised persons. ${ }^{31}$ The results also indicate that concentrations of $\mathrm{Cr}(\mathrm{VI})$ in soil due to chromite ore processing residue should not produce allergic contact dermatitis, even in $\mathrm{Cr}(\mathrm{VI})$ sensitised persons, below about $450 \mathrm{ppm}$. Our results indicate that traditional patch testing, which is used routinely to diagnose illness, can be modified so that the data can then be used to resolve issues in environmental medicine and quantitative risk assessment.

1 Marks JG, DeLeo VA. Contact and occupational dermatology. St Louis: Mosbey Year Book, 1992.

2 Burrows $D$, ed. Adverse chromate reactions on the skin In: Chromium metabolism and toxicity. Boca Raton Florida: CRC Press, 1983:138-58.

3 Burrows D, Adams RM. Metals. In: Adams RM, ed. Occupational skin disease, 2nd ed. Philadelphia: WB Saunders, 1990:349-86.

4 Levin HM, Brunner NJ, Ratner H. Lithographer's dermatitis $\mathcal{F A M A}$ 1959;169:566-9.

matitis $\mathcal{f} A M A 1959 ; 169: 566-9$.
5 Winston JR, Walsh EN. Chromate dermatitis in railroad employees working with diesel locomotives. $\mathfrak{\Im} A M A$ 1951;147:1133-4.

6 Morris GE. "Chrome" dermatitis: A study of the chemistry of shoe leather with particular reference to basic chromic sulfate. Arch Dermatol 1958;78:612-8.

7 Hostynek J, Maibach HI. Chromium in US household bleach. Contact Dermatitis 1988;18:206-9.

8 Paustenbach DJ, Sheehan PJ, Paull JM, Wisser LM, Finley BL. Review of the allergic contact dermatitis hazard posed by chromium-contaminated soil: Identifying a "safe" concentration. $\mathcal{F}$ Toxicol Environ Health 1992;37: "safe" conce

9 Adams RM, ed. Allergic contact dermatitis. In: Occupational skin disease. 2nd ed. Philadelphia: WB Saunders, 1990:26-31.

10 Ackerman AB. Histologic diagnosis of inflammatory skin disease. Philadelphia: Lea and Febiger, 1978:223-6.

11 Rook A, Wilkinson DS, Ebling FJ, Champion RH, Burton $\mathrm{JL}$, eds. Textbook of dermatology. Oxford: Blackwell Scientific, 1986:350-450.

12 Jackson EM, Goldmen R, eds. Irritant contact dermatitis. New York: Marcel Dekker Inc, 1990

13 Lammintausta KH, Maibach HI. Irritant dermatitis syndrome. Immunological Clinics of North America 1990;9:435-46.

14 Parkhurst HJ. Dermatosis industrials in a blueprint worker due to chromium compounds. Arch Dermatol 1925;15: due to

15 Pirilä V. On the role of chromium and other trace elements in cement eczema. Acta Derm Venereol 1954;34:137-43.

16 Zelger J. Zur Klinik und pathogenses dis chromate ekzems. Archives of Clinical and Experimental Dermatology 1964;218:499-542.

17 Zelger J, Wachter $\mathrm{H}$. Uber die beziehungen zwischen chromat-und dichromat-allergie. Dermatologica 1966; 132:45-50.

18 Burrows D, Calnan CD. Cement dermatitis II. Clinical aspects. Transactions of St fohn Hospital Dermatological Society 1965;51:27-39.

19 Skog E, Wahlberg JE. Patch testing with potassium dichromate in different vehicles. Arch Dermatol 1969;99: 697-700.

20 Anderson FE. Cement and oil dermatitis: the part played by chrome sensitivity. Br f Dermatol 1960;72:108-17.

21 Geiser JD, Jeanneret JP, Delacretaz J. Eczema au ciment et sensibilization au cobalt. Dermatologica 1960;121:1-7.

22 North American Contact Dermatitis Group (NACDG) Preliminary studies of the TRUE-Test ${ }^{\mathrm{TM}}$ patch test system in the United States. $\mathcal{F} \mathrm{Am}$ Acad Dermatol 1984;21:841-3.

23 ICDRG European Standard Series. Contact Dermatitis. 1994;11:63-4.
24 Fischer TI, Maibach HI. The thin layer rapid use epicutaneous test (TRUE-Test $\mathrm{T}^{\mathrm{TM}}$ ), a new patch test method with high accuracy. $B r \mathcal{F}$ Dermatol 1985;112:63-8.

25 New Jersey Department of Environmental Protection and Energy. Risk assessment of the allergic contact dermatitis potential of hexavalent chromium in contaminated soilderivation of an acceptable soil concentration. Draft by $\mathrm{Dr}$ Alan Stern, Division of Science and Research, Trenton, New Jersey NJDEPE, 9 June 1992.

26 Stern AH, Bagdon RE, Hazen RE, Marzulli FN. Risk assessment of the allergic dermatitis potential of environassessment of the allergic dermatitis potential of environEnviron Health 1993;40:613-41.

27 Paustenbach DJ, Jernigan JD, Bass R, Kalmes R, Scott P. A proposed approach to regulatory contaminated soil: Identify safe concentrations for seven of the most frequently encountered exposure scenarios. Reg Toxicol Pharmacol 1992;16:21-56.

28 Andersen KE, Linden C, Hansen J, Volund A. The degree of nickel allergy and the enhancing effect of multiple reactions evaluated by dose-response testing in allergic patients. First Congress of the European Society of Contact Dermatitis, Amsterdam, October 1992.

29 Upadhye MR, Maibach HI. Influence of area of application of allergen on sensitization in contact dermatitis. tion of allergen on sensitization

30 Fischer T, Maibach HI. Amount of nickel applied with a standard patch test. Contact Dermatitis 1984;11:285-7.

31 Horowitz SB, Finley BL. Setting health protective soil concentrations for dermal contact allergens: a proposed methodology. Regul Toxicol Pharm 1994;19:31-47.

32 Leung HW, Paustenbach DJ. Techniques for estimating dermal absorption of chemicals due to occupational and environmental exposure. Applied Occupational and Environmental Hygiene 1994;9:187-97.

33 Gammelgaard B, Fullerton A, Avnstorp C, Menne T. Permeations of chromium salts through human skin in vitro. Contact Dermatitis 1992;27:302-10.

34 Agency for Toxic Substances and Disease Registry. Toxicological profile for chromium. ATSDR/TP-88/10. Washington DC: ATSDR; US Public Health Service, 1989.

35 Rietschel RL, Marks JG, Adams RM, et al. Preliminary studies of the TRUE patch test system in the United States. F Am Acad Derm 1989;21:841-3.

36 Storrs FJ, Rosenthal LE, Adams RM, Clendenning W, Emmett EA, Fisher AA, et al. Prevalence and relevance of allergic reactions in patients patch tested in North America-1984 to 1985. F Am Acad Dermatol 1989; 20:1038-44.

37 Mali JWH, Van Kooten WJ, van Neer FCJ. Some aspects of the behavior of chromium compounds in the skin. f Invest Dermatol 1963;41:111-2.

38 Samitz MH, Katz SA. A study of the chemical reaction between chromium and skin. F Invest Dermatol 1964; 43:35-43.

39 Polak L. Immunology of chromium. In: Burrows D, ed. Chromium: metabolism and toxicity. Boca Raton, Florida: CRC Press, 1983:51-135.

40 Spruit D, van Neer FCJ. Penetration rate of $\mathrm{Cr}$ (III) and Cr(VI). Dermatologica 1966;132:179-82.

41 Kligman AM. The identification of contact allergens by human assay. III. The maximization test: a procedure for screening and rating contact sensitizers. F Invest Dermatol 1966;47:393-409.

42 Fregert S, Rorsman H. Allergy to trivalent chromium. American Medical Association Archives of Dermatology 1964;90:4-6

43 Fischer T, Maibach HI. Easier patch testing with TRUE Test $^{\mathrm{TM}}$. F Amer Acad Dermatol 1989;20:447-53.

44 Wright RW. Evaluation of contact dermatitis using the TRUE patch test. Fournal of the Arkansas Medical Society 1991;88:271-2.

45 Molina D, Abell MT. NIOSH manual of analytical methods, 3rd ed. Method No. 7600. NIOSH publ No 84-100. Cincinnati, Ohio: NIOSH, 1984.

46 California Air Resources Board. Ion chromatograph separa tion-colorimetry. Modified CARB SOP No MLD 105. Sacramento, California: CARB, 1990.

47 US Environmental Protection Agency. EPA Method 3060 SW-846. 3rd ed. September. Washington, DC: USEPA SW-846.
1986.

48 US Environmental Protection Agency. EPA Method 3050. SW-846. 3rd ed. September. Washington, DC: USEPA, 1986.

49 US Environmental Protection Agency. EPA Method 6010. SW-846. 3rd ed. September. Washington, DC: USEPA 1986.

50 Klaassen CD, Amdur MO, Doull J, eds. Cassarett and Doull's toxicology: the basic science of poisons. 4th ed. New York: Macmillan, 1992

51 Bagdon RE, Hazen RE. Skin permeation and cutaneous hypersensitivity as a basis for making risk assessments of chromium as a soil contaminant. Environ Health Perspect chromium as a soil

52 Maibach HI. The E.S.S excited skin syndrome (alias the "angry back"). In: Ring D, Burg B, eds. New trends in "angry back"). In: Ring D, Burg B, eds. New

53 Maibach HI, ed. Occupational and industrial dermatology, 2nd ed. Chicago: Year Book Medical, 1987: 28-31; 190-210.

54 Bruynzeel DP, van Ketel WG, von Blomberg M, Scheper RJ. Angry back or the excited skin syndrome. F Am Acad Dermatol 1983;8:392-7.

55 Nethercott JR. Results of routine patch testing of 200 
patients in Toronto, Canada. Contact Dermatitis 1982; 8:389-95.

56 Bagdon RE. Dermal absorption of selected chemicals under experimental and human exposure conditions to facilitate risk assessment and the development of standards for soil. Report to the Office of Science and Research Trenton, New Jersey: New Jersey Department of Trenton, New Jersey: New Jersey Deparument

57 Nethercott JR. Practical problems in the use of patch testing in evaluation of patients with contact dermatitis. In: Weston $\mathbb{W}$, ed. Current problems in dermatology, St Louis: Weston W, ed. Current problems in derm
Mosby-year Book Inc, 1990:101-23.

58 GENSTAT Reference Manual. GENSTAT 5, release 2.2 Oxford: Clarendon Press, 1982.

59 Rothman KJ. Modern epidemiology. Boston: Little, Brown, and Co 1987.

60 Armitage P, Berry G. Statistical methods in medical research. 2nd ed. Oxford: Blackwell Scientific Publications. 1987:485-6:495-6.

61 Paustenbach DJ, Sheehan PJ, Lau V, Meyer D. An assessment and quantitative uncertainty analysis of the health risks to workers exposed to chromium contaminated soils. Toxicol Ind Health 1991;7:159-96.
62 Weston WL, Weston JA. Allergic contact dermatitis in children. Am $\mathcal{F}$ Dis Child 1984;138:932-6.

63 Rudzki E, Rebandel P, Grzywa Z. Patch tests with occupational contactants in nurses, doctors and dentists. Contact Dermatitis 1989;20:247-50.

64 Heskel NS. Contact dermatitis in children. Dermatol Clin 1984;2:579-84.

65 Hjorth N. Contact dermatitis in children. Acta Derm Venereol (Stockh) 1981;S95:36-9.

66 Schachner I, Ling NS, Press S. A statistical analysis of a pediatric dermatology clinic. Pediatr Dermatol 1983;1: pediatric

67 Romaguera C, Alomar A, Camarasa JMG. Contact dermatitis in children. Contact Dermatitis 1985;12:283-4.

68 Tunnessen WW. A survey of skin disorders seen in pediatric general and dermatology clinics. Pediatr Dermato 1984;1:219-22.

69 Angelini G, Meneghini CL. Contact dermatitis in children. Pediatric Dermatology News 1987;6:195-204.

70 Finley BL, Horowitz SB. Using human sweat to extract chromium from chromite-ore processing residue: applications to setting health-based cleanup standards. f Toxicol Environ Health 1993;40:585-99.

\section{Vancouver style}

All manuscripts submitted to Occup Environ Med should conform to the uniform requirements for manuscripts submitted to biomedical journals (known as the Vancouver style.)

Occup Environ Med, together with many other international biomedical journals, has agreed to accept articles prepared in accordance with the Vancouver style. The style (described in full in the BMF, 24 February $1979, \mathrm{p} \mathrm{532}$ ) is intended to standardise requirements for authors.

References should be numbered consecutively in the order in which they are first mentioned in the text by Arabic numerals above the line on each occasion the reference is cited (Manson ${ }^{1}$ confirmed other reports $^{2-5}$. . .). In future references to papers submitted to Occup Environ Med should include: the names of all authors if there are seven or less or, if there are more, the first six followed by et al; the title of journal articles or book chapters; the titles of journals abbreviated according to the style of Index Medicus; and the first and final page numbers of the article or chapter. Titles not in Index Medicus should be given in full.

Examples of common forms of references are:

1 International Steering Committee of Medical Editors, Uniform requirements for manuscripts submitted to
biomedical journals. $B r$ Med $\mathcal{f} 1979 ; 1: 532-5$.

2 Soter NA, Wasserman SI, Austen KF. Cold urticaria: release into the circulation of histamine and eosinophil chemotactic factor of anaphylaxis during cold challenge. N Engl f Med 1976;294:687-90.

3 Weinstein L, Swartz MN. Pathogenic properties of invading micro-organisms. In: Sodeman WA Jr, Sodeman WA, eds. Pathologic physiology, mechanism of disease. Philadelphia: W B Saunders, 1974:457-72. 